\title{
Contextualised worship amongst the Nanticoke-Lenape American Indians
}

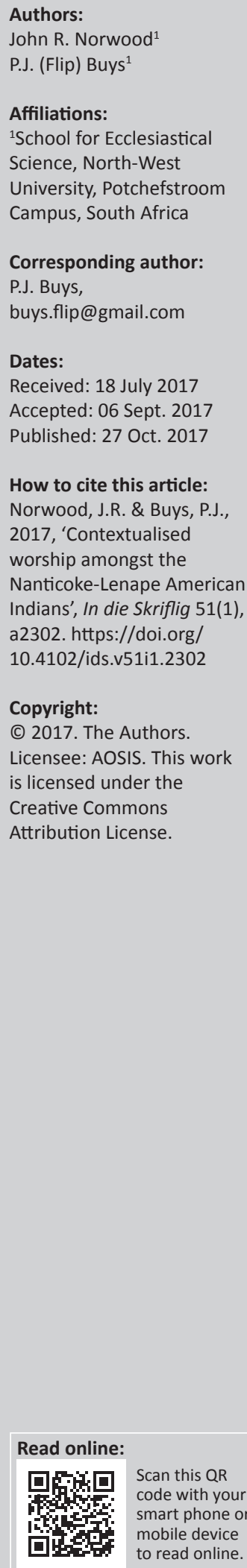

\begin{abstract}
The Christian history of the Nanticoke-Lenape people who live in three American Indian tribal communities of 'first contact' around the Delaware Bay (USA), is over three centuries old and continues in the contemporary tribal community congregations. The modern era of tribal cultural reprisal and rise of Pan-Indian neo-traditionalism has heightened an awareness of, and cast a critical eye on the absence of contextualisation in the regular worship of the tribal community churches. This article is a study in ethno-doxology and seeks to determine the need for contextualised worship, to analyse the challenges of contextualisation, and provide guidance for an approach to contextualisation of worship amongst the Nanticoke-Lenape Christian congregations.
\end{abstract}

\section{Introduction}

Around the area of the Delaware Bay, between the states of New Jersey and Delaware on the eastern seaboard of the United States, are three remaining communities of Native American or American Indian tribal people who have continued in their ancient homeland from before the time of the first contact with European explorers and colonisers. One community is in New Jersey in the area of Cumberland and Salem Counties, and two communities are in Delaware, in Kent and Sussex Counties. These indigenous people refer to themselves as 'Nanticoke' and 'Lenape', commonly hyphenated as 'Nanticoke-Lenape' (Gilbert 1948:408, 414-416; Price 1953:139, 145; United States Department of Commerce 2010). They are what remains of the Nanticoke and Lenape families who became the 'Keepers of the land' while the majority of the population of their tribal nations were forced out of the ancient homeland, westward as far as Oklahoma or northward as far as Canada because of European colonial expansion into their region during the seventeenth and eighteenth centuries. The title, Keepers of the land, is a reference used by their Canadian cousins describing their role as their tribal nations broke up into smaller surviving branches and communities during the years of forced migration (Blume 2008:218-219).

Made up of about 4000 tribal citizens between the three tribal communities, these keepers of the land attribute their ability to abide in their ancient homeland, at least in part, to the fact that their ancestors were Christianised (Weslager 2003:277) by the mid-eighteenth century and had their own congregations established early in the nineteenth century. However, their conversion to Christianity was without the benefit of contextualisation at a time when their traditional indigenous cultures were deemed to be 'savage' and 'pagan' by the western Christian colonisers. For generations their tribal identity and culture were deemed to be at odds with being Christian and civilised, at least from the majority perspective of the colonisers (Brinton 1885:62; Edwards \& Dwight 1822:344-345; Weslager 2003:283).

The last three generations have seen a cultural reprisal that is causing a re-evaluation of the relationship between Christianity and the indigenous tribal heritage. There is a unique opportunity for faithful contextualisation in worship, which may aid in a healing process addressing some of the spiritual and psychological wounds remaining from colonisation.

\section{Research questions}

Given more than three centuries of Christian mission amongst the Nanticoke-Lenape people, including the rise of tribal congregations, is there a need for contextualisation? Can the application of contextualised worship address any of the lingering wounds from colonisation? What are the challenges to remaining faithful to biblical Christianity while also embracing and adapting indigenous cultural forms and traditions into Christian worship amongst the Nanticoke-Lenape? 


\section{Methodology}

It should be noted that the author is a Nanticoke-Lenape, a Christian minister, and has served as a tribal leader for more than a decade. The author's purpose is to present the need for contextualisation of worship amongst Christians from a Nanticoke-Lenape background predominantly from an emic or insider perspective from within the social group, having a first-hand experiential understanding of the subject matter. Simultaneously, given the author's theological education at Princeton Theological Seminary (USA) and North-West University (South Africa), there is an additional aim of proposing ways to further the introduction of contextualised worship amongst Nanticoke-Lenape Christians from an etic or observer perspective, by considering predominant aspects of the current worldview and culture of the Nanticoke-Lenape.

Emic and etic perspectives need not be mutually exclusive approaches, but can be complementary methodologies in anthropological research. In studying human nature and interaction within human social systems, the complementary insider and observer perspectives can be illuminating (Xia 2011:77).

This article will briefly examine the context of Christianity amongst the Nanticoke-Lenape, utilising historical data, documented testimonies, contemporary statements of tribal people, and the personal 'insider' insights of the author. The challenges of contextualised worship and proposals for initiating it will be reviewed in the light of Scripture and the issues confronting the tribal community.

The terms, Native American, Indigenous American. and American Indian are applied synonymously in this article to refer to the aboriginal peoples of North America. However, given the prevailing preference commonly expressed amongst the Nanticoke-Lenape, American Indian will be the term primarily used. It should be noted that American Indian refers to those who are indigenous to the Americas and should not be confused with Indian American which commonly refers to an American citizen with ancestral origins from India.

\section{The context for contextualisation}

In the years of first contact between European colonisers and American Indians in North America during the sixteenth and seventeenth centuries, the Nanticoke-Lenape were amongst the tribes of the Atlantic Coast most affected by European diseases for which they had no immunity, resulting in as much as a 90 per cent reduction in their population by the mid-1800s (Dowd 2001:43; Fur 2009:203; Grumet 1995:239). The tribal families making up three communities around the Delaware Bay, following the break- up of some of the earliest Indian reservations in North America, chose to stay in the ancient homeland instead of migrating away with the majority of Nanticoke and Lenape people (Grumet 1995:239-240). Having been converted to Christianity, their strategy for survival included adapting to the way of life of the colonisers (Weslager 2003:277) as indigenous traditions and cultural traits were commonly condemned by the missionary colonisers, many of whom considered AngloEuropean culture as normative for what was deemed 'Christian' and 'civilized' (Blumm 2004:720; Bosch 2011:7456, 7180; Miller 2010:58-59, 62).

In spite of the pressure of colonisation to eradicate the indigenous culture, lingering aspects of the traditional cultural worldview that remain in varying degrees amongst the Nanticoke-Lenape include a notion of the interconnectedness of all creation, a spiritual connection to the land, and a sense of kinship with other creatures. The principles of harmony and balance are at the centre of the notion that all is connected; what affects one aspect of creation will, in some way, impact the rest of creation. This interconnectedness is one of the reasons for 'walking in a good way', which is a reference to the need for ethical and moral behaviour, or a call for righteous conduct. The connection to the land is expressed in the view that the earth is living, not necessarily with a spirit like that of humans and other animals, but that it possesses a type of life expressed in the harmony of the seasons and its ability to nourish other living things. Additionally, the past actions of ancestors in relationship to the land are viewed as having a sort of continuing existence, a living history to which the current community is connected. This connection to the land is related to the connection to other creatures of the land, the waters, and the air, with whom the Nanticoke-Lenape abide in a sacred harmony in accordance with the divine will. It is not unusual to hear an animal referred to as a 'relative' or spoken of in a manner that suggests some spiritual connection or shared characteristics. Traditional prayers often have petitions or thanksgivings related to the earth, its creatures, and seasons.

Amongst the older generation, history is not viewed as a series of past events somewhat disconnected from the current time, but rather as part of the current time. Tribal elders may speak of events that, to an uninitiated listener, may seem to have occurred relatively recently, but that upon further inquiry turn out to be from several generations ago.

The ancient reverence for dreams and visions continues in varying degrees within the tribal community. Some view these as forms of spiritual communication which grant insight into current or future events. Whether that communication is interpreted to be from ancestors, spirits, or the Creator will vary from person to person.

\section{Colonised Christian worship}

Amongst the three congregations which continue to be closely associated with the Nanticoke-Lenape tribal communities today, there are efforts to have expressions of cultural identity in some small aspects of the decor of the church sanctuaries and in certain occasional special services and celebrations. However, the full and regular integration of cultural forms in the worship life of the congregations has yet to be realised. Generally speaking, on a typical Sunday little 
or no contextualisation is evident. The cultural heritage of the congregations is not demonstrated in the overall and regular 'flavour' of worship. This is not unique to the NanticokeLenape tribal churches. The late Lakota/Sioux minister and missiologist, Richard Twiss, spoke of how many historically American Indian Christian congregations maintain a style of worship which is culturally indistinguishable from that of an Anglo-Euro-American congregation (Twiss 1998:5). When the contextualisation of one cultural perspective is viewed as normative for the faith, so much so that it is not thought of as contextual but axiomatic, the result can be a colonising approach to missions that causes undue damage to the recipients and their culture. It can also undermine the spiritual development of the missionary (Bosch 2011:293, 299; Bradshaw \& Savage 1974:1226; Twiss 2010: pt. 3, ch. 5). The colonised worship format must be addressed with compassionate patience, as generations of tribal and nontribal people have been acculturated to the perspective that tribal elements have no place, or at least no regular place in Christian worship.

It must be remembered that all worship is done within a context. This is true even when striving to strictly adhere to the regulative principle of worship, which guides reformed worship and defends against syncretistic practices. There are those who argue that, when the regulative principle of worship is appropriately applied, all Christian worship should look the same. However, this position appears to affirm that there is such a thing as a 'culturally neutral' manner of worship. Indeed, 'there is no such thing as a neutral, culture-free way to do anything' (Keller 2010:124). While the Reformers pursued the goal of worshiping in accordance with the Word of God, and perhaps came closer than most since the days of the Apostles in achieving it, they did so within a context. Cultural context impacts worldview, tastes, interactions, interpretations, and behaviour. It can be argued that the setting that has come down as 'culturally neutral' in American Reformed churches actually often demonstrates, perhaps unconsciously, a western perspective in everything from setting and style to aesthetic considerations. The regulative principle of worship allows for 'blended worship' (Lawrence \& Dever 2009:221) and allows for the principle to make worship intelligible to any unbelievers who may be present (1 Cor 14:24-25) through friendliness and informality and through music and language that may address the hearts of the worshipers. Contextualisation is applied by adapting the worship style to ethnic and socioeconomic groups other than the upper middle-class whites who dominate American Presbyterianism (Frame 1994: 61-62). Although the décor of any worship service is not a matter of principle it does serve a purpose to convey a message of incarnational ministry to people within their culture.

Additionally, while each of the tribal congregations maintains an historic and continuing relationship with the tribal communities, they no longer serve as the centre of tribal governance as they had done for many generations since the early to mid-nineteenth century. Over the past few decades, they have also become less homogeneous units through both intermarriages with non-Natives and demographic shifts in the surrounding population. Contextualisation efforts must take this into consideration so that the pursuit of embracing cultural expressions in the root historical context of the congregations does not send a message of alienation to nonNatives who have become part of the congregations.

\section{Historic intergenerational trauma}

The intergenerational devotion to Christ evidenced within the Nanticoke-Lenape tribal churches is certainly an indication that the mandate of Matthew 28:19, to go make disciples, is taken seriously by the congregations as a whole and also by the individual congregant families who have continued to pass the faith on to subsequent generations. While the propagation of the gospel is and should be the major concern, churches are also called to a ministry of healing and reconciliation. Ministries of compassion and pastoral care find expression in such actions as the feeding of the hungry and the provision of shelter to the homeless, the visiting of the sick, and the consoling of those that mourn.

An issue for pastoral attention and sensitivity amongst American Indian tribal communities is a type of posttraumatic stress disorder (PTSD) that has been identified amongst populations who have suffered such a deep loss that the psychological, social, and spiritual impact becomes multigenerational (Indian Country Diaries 2006). Called 'historic intergenerational trauma', it is associated with the sense of intense fear, helplessness, and horror experienced by combat veterans and survivors of torture, rape, natural and human-induced disasters. Such trauma was evidenced amongst the survivors of the Jewish Holocaust and their descendants (Brown-Rice 2014). This type of historic intergenerational trauma is now understood as one of the causes of many of the social problems amongst American Indian tribal communities (Indian Country Diaries, 2006). It is finding expression in a disproportionate rate of psychological distress, alcohol or substance abuse, a higher incidence of chronic illness, and issues of mental health when compared with nontribal communities in the United States (Urban Indian Health Institute 2012:1). A sense of depression over the history of the loss of territory, population, and culture combined with the contemporary pressures of the struggle for tribal cultural and political survival in modern America all contribute to the intergenerational aspects of this historic trauma (Brown-Rice 2014; Ehlers et al. 2013). This becomes a pastoral issue as insensitivity over the reality of this challenge within American Indian tribal communities can contribute to its perpetuation to future generations (Brown-Rice 2014).

The absence of contextualised worship often contributes, albeit unwittingly, to insensitivity over this issue. The lack of cultural expression in a tribal congregation continues to subtly communicate the misunderstanding that all that is tribal cannot be merged with what is Christian. This perpetuates an identity crisis, as it implies that one is either 
Christian, or American Indian, but not both. It can consign the indigenous believer to be bound in a westernised room and alienated from his or her indigenous culture (Whiteman n.d.). Moreover, when cultural expressions are relegated to being incorporated only in special or occasional worship services, the subliminal message is that such expressions are merely being tolerated for the moment but are inappropriate or unworthy for incorporation into the worship life of the congregation. This has the potential of creating an inner conflict amongst some American Indian Christians who must either deny their heritage in order to embrace their faith, hide their heritage from other people of the faith, or deny the faith in order to fully embrace their heritage. Within tribal communities, it can cause a sense of shame over one's cultural identity and incite conflict, instead of communication between tribal Christians and those tribal people who have rejected Christianity, who tend to view it as a culturedestroying tool of colonisation.

\section{Neo-traditionalism and anti-Christian sentiments}

The civil rights struggle in the United States during the 1950s and 1960s gave rise to a cultural awakening that had a unique impact amongst American Indians (Deloria 1988:169). There was a renewed sense of pride in one's tribal heritage, which had been suppressed through generations of suffering under the official federal policy to eradicate tribal culture and even terminate tribal governance in an effort to fully assimilate tribal people into the coloniser's culture, worldview and lifeways (Native American Rights Fund 2013:2; Talbot 2006:7). In an effort to promote cultural reprisal within the tribal community, often there is a sense that one must necessarily reject anything that had historically been forced upon the tribe or was used as an instrument of cultural destruction. Amongst American Indians, there are many who do not know the essential gospel of salvation by grace, but are very familiar with, and bitter about, the unfortunate and often horrific - history of interaction with Anglo-EuroAmerican church organisations and missionaries. Disdain for all things 'Christian' spread amongst the most radical of those seeking to reaffirm precolonial values and spiritual traditions in order to reclaim a maligned tribal identity and suppressed tribal culture (Wood 2011). For some, the lack of contextualisation in the life of the tribal church was interpreted as evidence that the churches were solely vestiges of colonisation that had to be rejected in order to fully realise cultural reprisal. Many tribal Christians found themselves intimidated by this neo-traditional movement, being left to feel as though they either had to remain quiet about their Christian convictions when participating in the life of the tribe, or turn away from tribal interactions and activities in order to remain faithful to Christ. The irony is that at one time, tribal believers were considered by non-Natives to be too tribal to be Christian, and now were considered by their neo-traditionalist tribal family members to be too Christian to be tribal. There is a need for contextualisation as an element of congregational life, missions, and pastoral care for such communities still affected by the throes of intergenerational trauma and where a lack of contextualised worship can potentially perpetuate the denigration of indigenous culture and identity.

\section{Challenges for contextualised worship}

Robert Wood (2011), editor of Mission Frontiers, defines contextualisation as follows:

[T]he process by which familiar cultural forms are adapted, redeemed and given new meaning in order to communicate the truths of Scripture to people on a deep heartfelt level.

Whiteman (n.d.) states: 'Essentially, contextualization is concerned with how the Gospel and culture relate to one another across geographic space and down through time'. The spread of Christianity from its first century PalestinianJewish roots to the modern context reveals a continuing struggle at the intersection between the faith and the culture to which it is ministering (Webber 1994:205). Contextualisation is modeled within Scripture itself (Davis 2008), with what is likely the most significant example being the incarnation of Jesus Christ. The Lord Jesus contextualised the good news of the kingdom by becoming one of the people to whom that good news was being given. His ministry was sensitive to the cultural context in which He lived. H. Richard Niebuhr (1951:39) wrote that 'The Son of God is himself child of a religious culture, and sends his disciples to attend his lambs and sheep, who cannot be guarded without cultural work'. When the Apostle John wrote in John 1:14 (ESV) that 'the Word became flesh and dwelt among us, and we have seen his glory, glory as of the only Son from the Father, full of grace and truth', he was describing divine activity that included the contextualisation of the bringer of redemption by the miracle of the incarnation. The contextualisation of the ministry of the good news of the kingdom of heaven can be seen in the preaching method of Jesus Christ. Jesus used illustrative language and parables, adapting his proclamation of heavenly things within the context of the history and culture of those who were listening. The things of everyday life were used to illustrate the truths of the kingdom. While Jesus himself explained that this was done in a fashion exclusively for those who had the divine gift of 'ears to hear' (Mt 13:9) and comprehend the mysteries of the kingdom, $\mathrm{He}$ nonetheless utilised everyday situations and commonalities to communicate these divine truths to those for whom it was given to understand ( $\mathrm{Mt}$ 13:11).

\section{Syncretism}

Faithful contextualisation of the gospel in worship requires a sense of cultural humility, acknowledging the ability of the Holy Spirit to utilise various forms from cultures that may be foreign to that of the missionary or minister in a manner that brings glory to God and edifies believers. The charge of syncretism should never be based on mere cultural preference or personal bias, but only on accurate, in-depth, doctrinal analysis. This sense of cultural humility must be matched with biblically faithful doctrinal discernment. 'For syncretism to be understood correctly ... it must be defined as a 
fundamentally doctrinal issue, not a socio-cultural one (Twiss 1998:3). Humility with discernment, charity with prudence, openness with judiciousness - such characteristics should be held in balance and prayerfully harmonised in the light of and in submission to Scripture. In the absence of harmonious balance, charity can lead to permissiveness, openness to error, and humility to indulgence. Contextualisation of the gospel supports evangelism and spiritual development. However, contextualisation can have its own thorny issues. One of the great challenges for contextualisation is to ensure that it remains faithful to Scripture and does not cross over doctrinal lines into syncretism. There are varying perspectives on a definition of syncretism. However, a plausible working definition of syncretism, as pertaining to Christianity and for our purpose, is the blending of beliefs and practices which are incompatible with biblical teaching, thereby creating a derived false faith which claims to be either Christian, compatible with Christianity, or a superior Christianity. Using this working definition, a typical tendency of syncretistic belief is to diminish the gospel of grace by denying the sufficiency of Christ's substitutionary atonement. Superstitious practices, rituals, and requirements are viewed as necessary for salvation and within the capacity of the believer to provide satisfactory, or supplementary, atonement. Another tendency of syncretism is the denial of the sufficiency, or reliability of Scripture. Other teachings, either written or orally transferred, are viewed as not merely being inspirational or encouraging, but actually equal to Scripture in regard to divine revelation and binding the conscience. Twiss (2005) posits:

Syncretism is $\sin$ in that it directs one's allegiance to other than Jesus Christ by reason of a person's participation in a new religious system - one created from the blend which dilutes or redirects faith to other than Christ.

Syncretism also occurs when what appears to be similar between contrary or opposing religions or philosophies are misinterpreted to value both as equal or the same (Twiss 2000:76).

Syncretistic tendencies are not unique to non-western settings, just as the human heart's tendency toward elements of idolatry is not purged because one may be western. A continuing 'spirit of Reformation' should always be applied to re-examine beliefs, perspectives, and practices which unconscious cultural biases may unwittingly embrace in an unreflective manner. The imperative of the Apostle Paul in Romans 12:2 applies equally to both the non-westerner and the westerner:

Do not be conformed to this world, but be transformed by the renewal of your mind, that by testing you may discern what is the will of God, what is good and acceptable and perfect. (ESV)

\section{Tribally specific indigenous contextualisation}

While there are many common cultural values shared amongst various American Indian tribes, there are also cultural differences. While the experience of colonisation may have common elements amongst many tribes across the continent, these experiences also varied by region, by tribe, and by era of initial contact. Contextualisation for a Northeastern tribe is different from contextualisation for the tribal cultures of the Great Plains or the Pacific Northwest because the cultural contexts, ancestral languages, spiritual beliefs and practices are not all the same. There are Christian denominations in the United States that seek to exemplify the characteristic of catholicity within the body of Christ by supporting agencies under their auspices which are charged with outreach to American Indian communities, the promotion of cross-cultural understanding, and the incorporation of indigenous cultural elements to be shared during special times and seasons by both tribal and nontribal churches. For denominational churches, such an affirmation of the value of American Indian cultural heritage as part of the rich diversity of the worldwide Christian family lays the needed groundwork upon which regional and tribally specific 'grassroots' contextualisation efforts may be developed. It is the regional and local church which has the opportunity to take this effort from general affirmation to tribally specific contextualisation. For those congregations in tribal communities, filled with indigenous people, tribally specific contextualisation need not be relegated to special times and seasons, but rather should be free to be a regular expression of cultural reprisal in praise of the Saviour.

\section{Introducing Nanticoke-Lenape cultural forms in worship}

The Nanticoke and Lenape have traditionally always been monotheistic (Danckaerts 1941:174-175; Heckewelder 1876:212) and even prior to exposure to the gospel, had a code of personal conduct which reflected many biblical Christian values (Brinton 1885:62-63; Lindstrom 1928:235; Penn 1970:30, 45). That is not to say that every historical spiritual practice or belief can be appropriated for purpose of contextualisation. Nor is it to say that even amongst the various contemporary religious perspectives of the tribal people today there is no hint of syncretism. However, there are cultural forms within the heritage of Nanticoke-Lenape people which can be appropriated for use in faithful, biblically consistent worship.

There is a need to introduce contextualised worship amongst the Nanticoke-Lenape in freeing believers to reclaim the culture God gave them and appropriately use its forms to celebrate their salvation in Jesus Christ, which is their new and greater identity. There is also a need for contextualisation in the effort to evangelise the non-Christian NanticokeLenape who have rejected the western cultural expressions that dominate their experience of Christianity to the exclusion of worshipful tribal culture and traditions, or the relegating of tribal expressions to only certain special days.

The setting of worship can speak volumes. Contextualisation of the ministry of the gospel towards Nanticoke-Lenape Christians must be holistic and therefore also applied in pastoral ministry and in considering what may be inadvertently communicated by the décor of the setting of 
worship. Given the backdrop of colonisation and domination, if the decor of the building or sanctuary is devoid of any trace of indigenous identity, it can send the signal that such things, along with the culture they represent and the people from which they come, may not be welcome. The place of worship need not be overtly aesthetically 'western' in order for this to be the case. Even in the absence of medieval artwork, there are elements that may still be 'western'. A 'plain' and 'unadorned' building or sanctuary to the Western eye may still have the beautiful pipes of an organ displayed; a prominent grand piano; pews arranged in a rectangular pattern facing an elevated pulpit; choir robes and pulpit gowns that may reflect European styles and patterns (sometimes of the colonial era). To the tribal person, such a 'plain' and 'unadorned' setting could still accentuate what is foreign and further emphasise the absence of what is indigenous. However, if the colours, patterns, and other adornments of the building reflect the crafts and artistry of the tribal people, there is an unspoken invitation for the tribal identity of the worshiper to be part of their expression of worship and to no longer be viewed as an emblem of shame to be repressed or denied. If possible, the set-up of the sanctuary seating in a more circular pattern can enhance the communal sense of the worship service and be a link to the way in which many traditional tribal ceremonies, social events, and meetings are conducted. Entryways and hallways that display indigenous artistic expressions of Christianity are non-verbal cues of welcome that may not need to be communicated in the same manner to a non-Indigenous worshiper. Also, outdoor worship can reflect the strong Nanticoke-Lenape relationship with creation, and can also be a wondrous vehicle to evangelise the passer-by.

\section{Concerning language, T.S. Eliot (2008) wrote:}

It must be remembered, that for the transmission of a culture - a peculiar way of thinking, feeling and behaving - and for its maintenance, there is no safeguard more reliable than a language. (p. 130)

While the Nanticoke language is all but lost, with only several hundred words recorded, its parent tongue, Lenape, is well preserved. Given that language is a dominant force in the transmission of culture, the use of the ancestral language, in calls to worship, prayers, litanies, songs, and blessings, celebrates cultural heritage, contradicts former policies which sought to eradicate tribal languages, affirms the universality of the gospel, calls to mind the experience of Pentecost (Ac 2:4-6), and can reinforce the local tribal community's language reprisal efforts. To be consistent with the principle of worship in the common tongue, it is important to ensure that any words or phrases are also provided or spoken in the common modern vernacular, which, for the Nanticoke-Lenape, happens to be English.

Tribal patterns and styles could be applied to choir outfits and clergy vestments, if such are part of church tradition. Worshipers should be comfortable wearing tribal garments, personal adornments, jewelry, moccasins (traditional footwear), or even full traditional tribal regalia, which is regionally and tribally specific. For the Nanticoke-Lenape, shell jewelry of the quahog and whelk, called 'wampum', reflect a unique characteristic of their northeastern tribal culture.

The inclusion of tribal instruments such as the drums and rattles can enhance the singing of traditional hymns and promote the addition of Christian tribal worship songs in Lenape and English. While drums and rattles are common across North American tribal cultures, with the war drum of the western plains being a ubiquitous presence in Pan-Indian powwow culture, the use of small water drums and turtle shell rattles are marks of Nanticoke-Lenape and other northeastern tribal cultures. Tribally inspired worship music can enhance the experience of worship for the indigenous believer. Preludes that incorporate the sound of the Indian flute, processionals that include the use of the water drum, hand drum or rattle, congregational songs using cultural phrases in the lyrics while focused on glorifying Christ, can all be significant steps in the contextualisation of worship. This need not be to the exclusion of western forms which are already well established, but can be an enhancement in addition to such forms or, even better, inform and even reshape such forms; it need not be an 'either or' but rather a 'both and'.

Just as Jesus preached and taught using illustrative elements common to his listeners, contextualised worship includes, and may be strategically introduced through culturally sensitive and biblically faithful homiletics. Sermon illustrations and applications can include cultural symbols, stories, practices, values, and lifeways which communicate the deep truth of a sermon text to the listeners in a manner that affirms their identity in Christ and can leave a lasting positive impression of indigenous heritage upon the entire congregation.

Initiating such cultural elements into the common worship experience requires pastoral patience, as some non-Native and even some Native congregants may need time to overcome negative preconceptions regarding indigenous expressions as the lingering, and erroneous bias that equates what is exclusively western with what is Christian, is overcome. Educating congregants as to the meaning and blessedness of appropriating cultural elements from the founding heritage of the congregation and continuing culture of many (if not most) within the congregation may be an ongoing task. However, the affirmation of the heritage of the indigenous people in whose land the congregation is located, is not merely for the spiritual healing of the indigenous congregants, but also for the edification of non-indigenous worshipers who grow to honour the blessings of God through the indigenous culture.

When Nanticoke-Lenape Tribal Christians come together for worship at tribal events, apart from the denominational congregations, various cultural forms are applied which render the 'style' unmistakably tribal. Amongst the tribal community in New Jersey, typically the prelude is done with a 'native flute' during a blessing of the place and the people 
with native natural 'incense' (typically cedar, sage, sweetgrass, or natural tobacco), called 'smudging'. The call to worship is in the Lenape language and is sung with a rattle, hand drum, or water drum keeping time. Those officiating will be in tribal regalia. The benediction is often in Lenape and sometimes followed by a closing song and fellowship dance with worshipers holding hands moving in a circle to the drum as a prayer song is sung. More could be said regarding the various ways that tribal forms are incorporated as expressions of worship; however, as this article is focused on the principles of contextualisation, an extensive evaluation of practical examples deserves an in-depth analysis and would more appropriately be the focus of another article.

\section{Summary}

This article briefly examined the issues around the introduction of contextualisation of worship for Christians in three interrelated indigenous tribal communities of Nanticoke-Lenape people remaining in their ancestral area of the Delaware Bay. From colonial times, Christianity's influence is evident in the history of each of the communities, in that, by the eighteenth century, a significant percentage of tribal people converted to Christianity, subsequently establishing in the nineteenth century tribal congregations which continue today. Yet, in the light of at least three centuries of well documented Christian influence within the tribal community, there is little evidence of contextualisation in worship. From colonial times, Christianity was presented and modeled in a fashion which denied the value of indigenous culture and identity in favour of that of the colonisers. Conversion was presented not only as a spiritual rebirth, but also included the imposition of what was viewed as 'civilisation' by the coloniser. While there are Christian congregations of the tribal people, cultural expressions are relegated to a few decorative items in the sanctuaries and the conduct of a few special and seasonal worship services. Otherwise, there is little indication of tribal heritage, other than the presence of tribal people in attendance. With cultural expressions and forms relegated to a few events annually, the subliminal message sent is that 'normal' worship is fashioned in an Anglo-Euro-American context with indigenous elements only occasionally tolerated as a special exception to the rule. This has caused anxiety and conflict amongst tribal people, especially during the past 50 years of cultural reprisal, pitting traditional ceremonial forms against Christianity. The rise of Pan-Indian neo-traditionalism has caused some tribal people to reject Christianity precisely because it has been presented as mandating assimilation into the culture of the colonisers and denunciation, or at least a minimisation of tribal heritage. Faithful contextualisation of worship is needed to address this dilemma.

The mishandling of the gospel through colonisation's imposition of a foreign culture as normative for Christian worship and civilisation has caused lingering harm to American Indians. A manifestation of this harm is historic intergenerational trauma. Contextualisation in the worship life of the Nanticoke-Lenape congregations is conducive to healing such historic wounds by affirming the validity of tribal heritage and identity through the inclusion of cultural forms. It affirms that Jesus Christ did not deliver tribal people from their culture, but redeemed tribal people in their culture. Through the contextualisation of worship, tribal people are empowered to express their adoration of the Lord Jesus Christ, utilising cultural forms which have survived by the grace and mercy of Jesus Christ, while maintaining their identity as Nanticoke-Lenape people. Contextualised worship affirms that one can be both Christian and American Indian. Contextualised worship allows for the reclaiming of one's tribal identity in one's walk of discipleship. Contextualised worship also affirms the dignity of tribal identity and heritage while still embracing non-Native worshipers and bringing reconciliation and healing.

While contextualisation can be supportive of cultural reprisal, first and foremost it must be biblically faithful. Congregations must be discerning in guarding against syncretism. However, one must also guard against personal cultural bias when evaluating cultural expressions. Cultural forms appropriated for use in Christian worship must be consistent with the gospel of grace. Such consistency may be inherent to the form itself, or be a renewed and redeemed interpretation of the form to the glory of Jesus Christ. Doctrinally sound contextualisation can be a deterrent to syncretism (Wood 2011). Additionally, while Pan-Indian cultural elements can be used to validate contextualisation and provide examples at national and denominational levels, individual congregations and regional judicatories have the opportunity, and perhaps even the responsibility, to identify and appropriate cultural forms consistent with the heritage of the historic tribe or tribes of their region.

\section{Conclusion}

Contextualisation efforts within the Christian congregations amongst the Nanticoke-Lenape can provide a form of healing, addressing the wounds and sins of historic colonisation, for both tribal and non-tribal worshipers. The research and cultural sharing involved in formulating biblically faithful and historically accurate contextualised worship can strengthen the bonds of fellowship and deepen cultural understanding and sensitivity within the congregation and between the church and the local tribal community. Embracing historic and specific tribal cultural expressions as typical and common for the worship life of a tribal community church can be a powerful witness and welcome to those who harbour hostility toward Christianity because of the history and continuing impact of colonisation. Overturning the erroneous presumption that being Christian and embracing tribal heritage and identity are mutually exclusive, can be a grace-filled initiative for reconciliation and evangelism.

Areas for further inquiry include moving from contextualisation of corporate worship to providing guidance in contextualised evangelism, spiritual formation, and pastoral care. This would be especially important in instances of cross-cultural ministry. Additional research would assist in identifying various modes 
and methods for developing a framework for ongoing interaction between the local congregation and its surrounding tribal community.

\section{Acknowledgements}

J.R.Norwood Jr is a Christian pastor, serves as a tribal leader of the Nanticoke Lenni-Lenape Tribal Nation (USA), and earned a PhD in Missiology from the North-West University (South Africa) under the leadership of Prof. P.J. Buys. This article is based on research for the doctoral dissertation of John Norwood.

\section{Competing interests}

The authors declare that they have no financial or personal relationships which may have inappropriately influenced them in writing this article.

\section{Authors' contributions}

This article is the outflow of the PhD doctoral research for J.R.N. who was the project leader and field researcher. P.J.B. was responsible for advice, guidance, quality control and supervision of the research that led to this article.

\section{References}

Blume, C.L., 2008, 'Working with the keepers of the land: Creating partnerships for preservation and management', in F.P. McMannamon, A. Stout \& J.A. Barnes (eds.), Managing archaeological resources: Global context, national programs, local actions, pp. 217-232, Left Coast Press, Walnut Creek.

Blumm, M.C., 2004, 'Retracing the discovery doctrine: Aboriginal title, tribal sovereignty, and their significance to treaty-making and modern natural resources policy in Indian country', Vermont Law Review 28, 713, viewed 30 September 2013, from http://www.heinonline.org.nwulib.nwu.ac.za/HOL/Page
vlr28\&id=723\&collection=journals\&index=journals/vlr\#723

Bosch, D.J., 2011, Transforming mission: Paradigm shifts in theology of mission, Orbis Books, Maryknoll. [Kindle edn.]

Bradshaw, M. \& Savage, P., 1974, 'The gospel, contextualization and syncretism report', in Let the earth hear his voice: The International Congress on World Evangelism, July 16-25, Lausanne, Switzerland, viewed 23 February 2015, from http://www.lausanne.org/docs/lau1docs/1224.pdf

Brinton, D.G., 1885, 'The Lenape and their legends with the complete text and symbols of the Walam Olam', in Brinton's library of aboriginal American literature, no. 5 Brinton, Philadelphia, viewed 26 April 2013, from http://ia700307.us. archive.org/26/items/lenptheirleg00brin/lenptheirleg00brin_bw.pdf

Brown-Rice, K., 2014, 'Examining the theory of historical trauma among Native Americans', The Professional Counselor, October, viewed 9 February 2015, from http://tpcjournal. nbcc.org/examining-the-theory-of-historical-trauma-among-native-americans/

Danckaerts, J., 1941, Journal of Jasper Danckaerts, 1679-1680, B.B. James \& J.F. Jameson (eds.), Barnes \& Noble, New York, viewed 17 April 2013, from http:// archive.org/details/journalofjasperd00danc

Davis, S.M., 2008, 'Contextualization: Theological and missiological necessity', Sharper (2008/08/11/contextualization-theologicat-anc

Deloria, V., Jr., 1988, Custer died for your sins: An Indian manifesto, University of Oklahoma Press, Norman.

Dowd, G.E., 2001, The Indians of New Jersey, New Jersey Historical Commission, Trenton. (New Jersey history series, no. 3).

Edwards, J. \& Dwight, S.E., 1822, Memoirs of the Rev. David Brainerd, missionary to the Indians on the borders of New York, New Jersey, and Pennsylvania: Chiefly taken from his own diary, S. Converse, New Haven, viewed 08 March 2013, from http://books.google. com/books/about/Memoirs_of_the_Rev_David_Brainerd.html?id=17oRAAAAYAAJ

Ehlers, C., Gizer, I., Gilder, D., Ellingson, J. \& Yehuda, R., 2013, 'Measuring historical trauma in an American Indian community sample: Contributions of substance dependence, affective disorder, conduct disorder and PTSD', Drug and Alcohol Dependence 133, 180-187, viewed 09 February 2015, from http:// eds.b.ebscohost.com.nwulib. nwu.ac.za/eds/detail/detail?vid $=4 \&$ sid $=2 \mathrm{f} 1871 \mathrm{f3}$ 21de-4d07-b778-b844fe31a9a3\%40sessionmgr111\&hid=122\&bdata=JnNpdGU9 ZWRzLWxpdmU\%3d\#db=edselp\&AN=S0376871613001865
Eliot, T.S., 2008, Christianity and culture: The idea of a Christian society and notes towards the definition of culture, Harcourt, Brace, New York. [Kindle edn.].

Frame, J., 1994, 'The regulative principle', in R. Webber (ed.), The ministries of Christian worship, 1st edn., vol. 7, pp. 61-62, Star Song Pub. Group, Nashville.

Fur, G., 2009, A nation of women: Gender and colonial encounters among the Delaware Indians, University of Pennsylvania Press, Philadelphia.

Gilbert, W.H., 1948, Surviving Indian groups of the eastern United States, Annual report of the Board of Regents of the Smithsonian Institution, Pub. 3954, United States Government Printing Office, Washington.

Grumet, R.S., 1995, Historic contact: Indian people and colonists in today's northeastern United States in the sixteenth through eighteenth centuries, University of Oklahoma Press, Norman.

Heckewelder, J.G., 1876, History, manners and customs of the Indian nations who once inhabited Pennsylvania and the neighboring states, Historical Society of Pennsylvania, Philadelphia.

Indian Country Diaries, 2006, 'Historic trauma may be causing today's health crisis', Native American Public Telecommunications, September, viewed 09 February 2015, from http://www.pbs.org/indiancountry/challenges/ trauma.html

Keller, T., 2010, Generous justice: How God's grace makes us just, Penguin, New York.

Lawrence, M. \& Dever, M., 2009, 'Blended worship', in J.L. Duncan, D. Kimball, M. Lawrence, T.C.L. Quill, D. Wilt, M. Dever \& J.M. Pinson (eds.), Perspectives on Christian worship: 5 views: Ligon Duncan, Dan Kimball, Michael Lawrence \& Mark Dever, Timothy Quill, Dan Wilt, p. 221, B\&H Academic, Nashville, TN.

Lindstrom, P.M., 1928, Geographia Americae: With an account of the Delaware Indians, Scandinavians in America [Swedish Colonial Society, Philadelphia, 1979], illustrated reprint edition, S. Bedney (ed.) Arno, New York.

Miller, R.J., 2010, Christianity, American Indians, and the doctrine of discovery, remembering Jamestown, Lewis \& Clark Law School Legal Studies Research Paper Series, S.F. Mandiberg (ed.), Lewis \& Clark Law School, Portland, OR, viewed 30 September 2013, from http://papers.ssrn.com/sol3/papers.cfm?abstract_id= 1803674\#\#

Native American Rights Fund, 2013, 'Let all that is Indian within you die!', Legal Review 38(2). [Handout report.]

Niebuhr, H.R., 1951, Christ and culture, 2001 edn., Harper Collins, New York.

Penn, W., 1970, William Penn's own account of the Lenni Lenape or Delaware Indians, A.C. Meyers (ed.), Middle Atlantic Press, Moorestown, NJ.

Price, E.T., 1953, 'A geographic analysis of White-Negro-Indian racial mixtures in eastern United States', Annals of the Association of American Geographers 43(2), June, viewed 09 March 2008, from http://links.jstor.org/sici?sici=0004-5608\% 28195306\%2943\%3A2\%3C138\%3AAGAOWR\%3E2.0.CO\%3B2-A

Talbot, S., 2006, 'Spiritual Genocide: The denial of American Indian religious freedom, from conquest to 1934', Wicazo Sa Review 21(2), 7-39. https://doi.org/10.1353/ wic.2006.0024

Twiss, R.L., 1998, Dancing our prayers: Perspectives on syncretism, critical contextualization and cultural practices in first nations ministry, revised edition 2002, Wiconi Press, Vancouver, WA.

Twiss, R.L., 2000, One church many tribes: Following Jesus the way God made you, Regal Books, Ventura, CA.

Twiss, R.L., 2005, 'Syncretism - A work in progress by Richard Twiss: Reflections on the widespread concern about syncretism in Native North American and indigenous ministry', viewed 27 October 2014, from http://richardtwiss.blogspot.com/2005/ 01/syncretism-work-in-progress-by-richard.html

Twiss, R.L., 2010, 'Living in transition, embracing community, and envisioning God's mission as trinitarian mutuality: Reflections from a Native-American follower of Jesus', in A. Young \& B.B. Zikmund (eds), Remembering Jamestown: Hard questions about Christian mission, pp. 93-108, Pickwick Publications, Eugene, OR.

United States Department of Commerce, 2010, American Indians and Alaska Natives in the United States wall map, United States Census Bureau, Washington, DC viewed 23 March 2013, from http://www.census.gov/geo/www/maps/aian2010 wall_map/aian_wall_map.html

Urban Indian Health Institute, Seattle Indian Health Board, 2012, Addressing depression among American Indians and Alaska Natives: A literature review Urban Indian Health Institute, Seattle, WA, viewed 09 February 2015, from http:// www.uihi.org/wp-content/uploads/2012/08/Depression-Environmental-Scan_ All-Sections_2012-08-21_ES_FINAL.pdf

Webber, R., 1994, The ministries of Christian worship, 1st edn., vol. 7, Star Song Pub. Group, Nashville, TN.

Weslager, C.A., 2003, The Delaware Indians, Rutgers University Press, New Brunswick, NJ.

Whiteman, D.L., n.d., 'Contextualization: The theory, the gap, the challenge', viewed 24 February 2016, from http://spu.edu/temp/denuol/context.htm

Wood, R., 2011, 'Overcoming syncretism by contextualization', Contextualization of Global Missiology 2(8), January, viewed 27 October 2014, from http://ojs. globalmissiology.org/index.php/english/article/view/452/1167

Xia, J., 2011, 'An anthropological emic-etic perspective on open access practices', Journal of Documentation 67(1), 75-94. https://doi.org/10.1108/00220411111105461 